\title{
Solubility Enhancement of Ethyl AcetateFraction of The Artocarpus altilis (Parkinson) Fosberg Leaves with Addition of $\beta$-Cyclodextrin- HPMC by Using Kneading Method
}

\author{
Sabrina $^{* 1}$, Yuni Anggraeni ${ }^{1}$, Berti Puspitasari1, LBS Kardono ${ }^{2}$ \\ 1 Program Studi Farmasi, Fakultas Kedokteran dan Ilmu Kesehatan UIN Syarif Hidayatullah, Jakarta \\ 2 Pusat Penelitian Kimia, Lembaga Ilmu Pengetahuan Indonesia, Serpong Tangsel. \\ *Email : sabrina043@yahoo.com
}

\begin{abstract}
Ethyl acetate fraction of the Artocarpus altilis (Parkinson) Fosberg extract have a potency to treat the cardiovascular diseases have poorly solubility in water. The purpose of this study was to improve the solubility of the extract. One of method to improve the solubility of the extract by mixing with cyclodextrin polymers and their derivatives. Hydroxyl propyl methylcellulose (HPMC) as a water-soluble polymer can enhance the $\beta$-cyclodextrin ( $\beta$-CD) activity. Three comparisons extract and $\beta$-cyclodextrin were: 1:2, 1:4, and $1: 6$ by mixing with the addition hydroxyl propyl methylcellulose $0.12 \%$ of the total weight of extract and $\beta$ $\mathrm{CD}$ for each formula. The sample was prepared by kneading method. The sample characterization was used Karl Fischer titration, Scanning Electron Microscopy and solubility study.Content of total flavonoid from the extract was $32.7 \%$. The Result showed that the addition polymer combination of $\beta$-CD + HPMC caused increasing the solubility of extract in water7.04\% (F1), 19.47\% (F2) and 59.92\% (F3) compared to extract control with significant differences at level of confidence $95 \%$ ( $p \leq 0.05)$.
\end{abstract}

Keywords : ethyl acetate fraction of breadfruit, kneading method, $\beta$-cyclodextryn, hydroxy propyl methylcellulose, total flavonoid

\section{PENDAHULUAN}

Daun sukun efektif mengobati penyakit seperti liver, hepatitis, pembesaran limpa, jantung, ginjal, tekanan darah tinggi dan kencing manis, karena mengandung fenol, quersetin, kaemperol dan juga dapat digunakan sebagai bahan ramuan obat penyembuh kulit yang bengkak atau gatalgatal (Soemyarso, 2007). Studi in vitro dan in vivo pada ekstrak daun sukun menunjukkan bahwa senyawa flavonoid yang terkandung di dalamnya dapat digunakan sebagai obat kardiovaskular (Umar et al, 2007). Senyawasenyawa aktif dari golongan flavonoid yang ditemukan dalam fraksi etil asetat daun sukun, diantaranya DS6 atau 1-4(2,4 Dyhydroxylphenyl)-3-[8-hydroxy-2-methyl2-(4-methyl-3-pentenyl)-2H-1-benzoperan5-yl]-1-propanone, sebagai obat kardiovaskular dan anti kanker, 2-geranyl2',3,4,4'-tetrahydroxychalcone sebagai obat kardiovaskular juga senyawa antikanker (carcinostatic) yang diberikan baik secara oral maupun parenteral (Syah et al., 2006).
Dari uraian di atas terlihat bahwa kandungan flavonoid dari fraksi etil asetat daun sukun memiliki potensi yang besar dalam pengobatan. Oleh karena itu perlu dilakukan penelitian lebih lanjut mengenai fraksi etil asetat daun sukun yang dapat digunakan sebagai obat fitofarmaka.

Fraksi etil asetat daun sukun (FEAS) memiliki kelarutan yang rendah dalam air. Absorpsi obat-obatan yang kelarutannya rendah dalam air berpengaruh terhadap rendahnya bioavaibilitas obat tersebut dalam tubuh yang mempengaruhi efek terapeutik obat (Lieberman, Lachman dan Schwartz, 1989; Talari et al., 2010). Oleh karena itu perlu dicari metode yang tepat untuk meningkatkan kelarutan dari fraksi etil asetat daun sukun. Salah satu metode untuk meningkatkan kelarutan adalah dengan penambahan polimer kombinasi $\beta$ siklodekstrin dan hidroksi propil metilselulosa menggunakan metode pencampuran kneading (Saraf et al., 2011). 
Pembuatan kompleks inklusi dengan siklodekstrin telah terbukti berhasil dalam meningkatkan kelarutan obat-obatan yang memiliki kelarutan rendah dalam air (Hiremath et al., 2008). Hal tersebut disebabkan adanya interaksi antara molekul tamu dengan siklodekstrin. Pembentukkan kompleks inklusi yang terjadi dalam rongga hidrofobik di bagian dalam dan gugus hidrofilik di bagian luar permukaan siklodekstrin dapat menyebabkan modifikasi sifat kimia dan fisik dari molekul tamu, sehingga terjadi peningkatan stabilitas, kelarutan dalam medium berair dan bioavailabilitas obat (Chandrakant et al., 2010; Shewale, Fursule, dan Sapkal., 2008).

Telah dilaporkan bahwa, penambahan beberapa polimer larut air dapat meningkatkan kekuatan siklodekstrin terhadap peningkatan kelarutan obat, sebagai akibat dari efek gabungan dari pembentukan garam dan kompleksasi inklusi (Chawla et al., 2008; Cirri et al., 2004). Misalnya, penambahan sejumlah kecil Hidroksi Propil Metilselulosa (HPMC) ke sistem Meloxicam$\beta$-CD meningkatkan efisiensi pengompleks dan pelarut dari $\beta$-CD (Saraf et al., 2011).

Siklodekstrin (CD) berasal dari kelompok molekul siklik alami atau sintetis yang dimodifikasi, biasanya terdiri dari enam $(\alpha-C D)$, tujuh $(\beta-C D)$ dan delapan $(\gamma-C D)$ unit glukopiranosa. Oligomer siklik ini menghubungkan unit glukosa melalui siklik $\alpha(1,4)$, memiliki bentuk toroida dengan bagian dalam apolar dan dua hidrofilik rims, sehingga memungkinkan solubilisasi mereka dalam air (Cannava et al., 2008). Hubungan unik ini mempengaruhi $\mathrm{CD}$ untuk membentuk mikrokapsul molekul, yaitu kompleks tuan rumah-molekul tamu, sebagai perpindahan molekul air dimasukkan oleh substrat apolar yang merupakan proses termodinamika. Pengikatan antara molekul tamu dan tuan rumah siklodekstrin tidak tetap atau permanen melainkan kesetimbangan yang dinamis (Cannava et al., 2008). meningkatkan kelarutan fraksi etil asetat daun sukun dengan penambahan polimer kombinasi $\quad \beta$-siklodekstrin+HPMC menggunakan metode pencampuran kneading. Ruang lingkup penelitian ini mencakup karakterisasi fraksi etil asetat daun sukun, pembuatan campuran fraksi etil asetat daun sukun dengan penambahan polimer $\beta$ siklodekstrin+HPMC melalui metode kneading, karakterisasi campuran fraksi etil asetat daun sukun dan $\beta$ siklodekstrin+hydroxyl propyl methylcellulose menggunakan titrasi karl fisher dan pemindaian mikroskop elektron (SEM), uji kelarutan campuran fraksi etil asetat daun sukun $-\beta$-siklodekstrin+HPMC.

\section{METODE PENELITIAN}

\section{Alat dan Bahan}

Fraksi etil asetat daun sukun kering (LIPI-Serpong), betasiklodekstringrade analysis (Wako, Jepang), HPMCgrade analysis (Wako, Jepang), Rutin (LIPICibinong), etanol (Merck, Jerman), $\mathrm{HCl} \mathrm{0,1}$ $\mathrm{N}$, aquadest, aquabidest, metanol HPLC grade (JT Beker).

Alat-alat gelas, mortar dan alu, ayakan no. 100, desikator, neraca analitik, magnetic stirrer, shaker waterbath, termometer, filter membran $0,20 \mu \mathrm{m}$, kertas saring, tanur, moisture balance, SpektroUVLambda 25 (Perkin Elmer, Jerman), Karl fischer moisture titrator MKS 520 (KEM), Scanning electron microscopy (JEOL, Jepang).

\section{Organoleptis}

Mengamatai bentuk, warna, dan bau dari fraksi etil asetat daun sukun.

\section{Penentuan Kadar Total Flavonoid}

Sebanyak $10 \mathrm{mg}$ fraksi etil asetat daun sukun kering ditimbang kemudian dilarutkan dengan metanol grade HPLC dan di ad hingga $10 \mathrm{~mL}$ (1000 ppm). Larutan sampel dipipet $0,1 \mathrm{~mL}$ dan ditambahkan metanol grade HPLC hingga $10 \mathrm{~mL}(10$ ppm). Kemudian larutan dianalisa dengan spektrofotometer UV-VIS. Dibuat larutan 
rutin dengan konsentrasi 10, 20, 30, 40 dan 50 ppm sebagai larutan standar.

Kadar Abu Total ( Depkes RI, 2000)

Sebanyak 2 gram serbuk FEAS ditimbang dan dimasukkan ke dalam krus telah dipijarkan dan ditara. Kemudian dimasukkan ke dalam tanur dan dipijarkan hingga bobot tetap. Sampel diangkat, didinginkan dalam eksikator dan ditimbang. Jika dengan cara ini arang tidak dapat dihilangkan, tambahkan air panas lalu saring dengan kertas saring bebas abu. Residu dan kertas saring dalam krus yang sama dipijarkan. Filtrat dimasukkan ke dalam krus, diuapkan, dan dipijarkan hingga bobot tetap, lalu ditimbang. Kadar abu dihitung terhadap bahan yang telah dikeringkan di udara.

\section{Kadar Air}

Kadar air dilakukan dengan menggunakan alat karl fischer titration. Sampel ditimbang sebanyak 1 gram (W1). Mengalibrasi alat dengan menetralisir pelarut metanol kering menggunakan pelarut hydranal, kemudian sampel dimasukkan apabila alat sudah netral. Sampel dimasukkan sedikit ke dalam pelarut metanol kering. Sampel yang tersisa ditimbang kembali sehingga diperoleh bobot akhir (W2). Data W1 dan W2 yang diperoleh dimasukkan ke alat karl fischer titration kemudian dicatat hasil persentasi kadar air dari sampel.

\section{Susut Pengeringan (Depkes RI, 2000).}

Susut pengeringan dilakukan dengan menggunakan alat moisture balance.Alat dikalibrasi terlebih dahulu. Plat aluminium ditara dan ditimbang, kemudian sampel dimasukkan ke dalam plat senayak 5 gram kemudian alat di set dengan suhu $105^{\circ} \mathrm{C}$ selama 4 menit atau sampai bobot tetap. Catat hasil pengukuran.

\section{Pembuatan Campuran Menggunakan Metode Kneading}

Pencampuran dilakukan dengan 3 variasi perbandingan berdasar pada peningkatan jumlah siklodestrin tiap formulasi. Perbandingan FEAS : $\beta$-CD yaitu 1:2 (formula 1), 1:4 (formula 2), 1:6 (formula 3). Penambahan HPMC sebanyak $0,12 \% \mathrm{~b} / \mathrm{b}$ dari bobot total untuk masing-masing formulasi (Saraf et al., 2011).

Sampel (FEAS), ß-siklodekstrin dan HPMC ditimbang sesuai dengan formula diatas. Kemudian dilakukan pencampuran polimer kombinasi yaitu ß-siklodekstrin dan HPMC dalam mortar dan ditambahkan etanol $50 \%$ hingga didapatkan konsistensi slurry (pasta). Secara perlahan ditambahkan sampel FEAS kedalam pasta dan pengadukan dilanjutkan selama 45 menit. Campuran dikeringkan pada suhu $45^{\circ} \mathrm{C}$ selama 48 jam dalam oven, lalu dipulverisasi, dan dilewatkan melalui ayakan no 100 yang selanjutnya disimpan dalam desikator (Vikesh, Rajashree, Ashok, Fakirappa, 2009).

Tabel 1. Formulasi campuran FEAS- $\beta$-siklodekstrin+HPMC

\begin{tabular}{|c|c|c|c|c|}
\hline Metode Kneading & Perbandingan & $\begin{array}{c}\text { FEAS } \\
(\mathrm{mg})\end{array}$ & $\begin{array}{c}\beta \text {-siklodekstrin } \\
(\mathrm{mg})\end{array}$ & $\begin{array}{c}\text { HPMC } \\
0,12 \% \mathrm{~b} / \mathrm{b} \\
(\mathrm{mg})\end{array}$ \\
\hline Formula 1 & $1: 2$ & 500 & 1000 & 1,8 \\
\hline Formula 2 & $1: 4$ & 500 & 2000 & 3 \\
\hline Formula 3 & $1: 6$ & 500 & 3000 & 4,2 \\
\hline
\end{tabular}

\section{Karakterisasi Campuran FEAS- $\beta$ - siklodekstrin+HPMC dengan Scanning Electron Microscopy (SEM)}

Uji dilakukan terhadap FEAS, campuran

FEAS- $\beta$-siklodekstrin+HPMC Disiapkan sebuah silinder yang bagian bawahnya telah ditempelkan dengan plat tembaga. Sejumlah serbuk sampel direkatkan 
tape.Kemudian sampel yang merekat pada double tape diberikan sebuah tekanan udara. Silinder kemudian ditempelkan pada double tape yang telah bertabur serbuk sampel. Kemudian silinder di coating dan diuji menggunakan SEM dengan tegangan $25 \mathrm{kV}$ x300 $\times 3000 \times$ besarnya untuk tingkat, dan fokus dari 10-14,1 mm

\section{Uji Karl Fisher}

Uji dilakukan terhadap FEAS, polimer kombinasi $\beta$-siklodekstrin+HPMC, campuran FEAS-ß-siklodekstrin + HPMC. Prosedur kerja sama dengan penentuan kadar air.

\section{Uji Kelarutan}

Uji kelarutan dilakukan menurut metode yang dikemukakan Higuchi dan Connors. Ditimbang sejumlah $\pm 10 \mathrm{mg}$ FEA, Formula 1, 2, dan 3 yang ditimbang setara dengan FEAS yang terkandung dalam campuran. Lalu dimasukkan ke dalam vial dan ditambahkan $10 \mathrm{~mL}$ medium berupa aquabidest, kemudian dishaker selama 72 jam (Ferdianan et al., 2006). Larutan yang diperoleh disaring dengan filter membran $0.20 \mu \mathrm{m}$. Dari setiap formula dipipet $0.1 \mathrm{~mL}$ kemudian ditambahkan $10 \mathrm{~mL}$ menggunakan metanol dan dianalisa dengan spektrofotometer UV-Vis. Konsentrasi dihitung dengan menggunakan persamaan regresi yang diperoleh pada pembuatan kurva dengan memasukkan nilai luas area sebagai fungsi y (Corciovia dan cascaval, 2011)

\section{Analisa Data}

\section{Hasil uji kelarutan dilakukan analisa data dengan menggunaka program pengolahan data statitistik uji $\mathrm{T}$ yaitu paired sample dan independent sample.}

Hipotesis

Ho :tidak ada perbedaan yang bermakna antara peningkatan kelarutan fraksi etil asetat daun sukun terhadap formulasi.

H' $\quad$ :terdapat perbedaan yang bermakna antara peningkatan kelarutan fraksi etil asetat daun sukun terhadap formulasi.
Bila nilai sig $\leq 0,05$ Ho ditolak, berarti terdapat perbedaan.

Bila nilai sig $\geq 0,05$ Ho diterima, berarti tidak terdapat perbedaan.

\section{HASIL DAN PEMBAHASAN Karakteristik Fraksi Etil Asetat Daun Sukun}

Fraksi etil asetat daun sukun pada penelitian ini diperoleh dari Pusat Penelitian Kimia LIPI Serpong, dihasilkan dengan cara ekstraksi menggunakan etanol $70 \%$ dari daun sukun tua dan kering, ekstrak etanol dipartisi dengan n-heksana kemudian fase air dipartisi dengan etil asetat yang kemudian hasil berupa ektrak fraksi etil asetat kering (Umar et al., 2007). Data parameter spesifik yang berupa parameter organoleptik bertujuan memberikan pengenalan awal bahan secara objektif berupa bentuk warna, bau, dan rasa yang dapat dipengaruhi oleh penyimpanan sehingga mempengaruhi khasiatnya. Organoleptik serbuk fraksi etil asetat daun sukun memiliki bentuk padat, berwarna hijau kecoklatan, berbau tajam, dan berasa tawar.

Penentuan kadar total flavonoid fraksi etil asetat daun sukun dilakukan dengan senyawa kimia penanda flavonoid rutin yang digunakan sebagai kurva baku yang bertujuan untuk mengetahui senyawa kimia spesifik yang terdapat di dalam ekstrak tersebut baik secara kualitatif maupun kuantitatif (Azis et al., 2011).

Pemilihan senyawa rutin sebagai senyawa penanda dikarenakan sebagian besar senyawa flavonoid yang terdapat di alam adalah golongan flavonol salah satunya senyawa rutin dan quercetin (Markham, 1970). Spektrum penyerapan flavonoid terdiri dari dua pita yang terdapat pada kisaran 240-400 nm. Pita I meliputi kisaran panjang gelombang 300-380 nm, yang berhubungan dengan cincin $\mathrm{B}$ dengan $\mathrm{A}$ max berkisar antara 350-380 nm. Sedangkan pada pita II terdapat pada kisaran panjang gelombang 240-280 $\mathrm{nm}$ yang berhubungan dengan cincin A-C dengan A max 260-270 nm (Cvetkovic, Markovic, dan Radovanovic, 
Tabel 2.Hasil Karakteristik Fraksi Etil Asetat Daun Sukun

\begin{tabular}{cc}
\hline JenisKarakteristik & Hasil \\
\hline Spesifik & \\
\hline Bentuk & Padat \\
Warna & Coklat Kehijauan \\
Bau & Tajam \\
Rasa & Tawar \\
Kadar Total Flavonoid & $32,7 \%$ \\
\hline Non-Spesifik & \\
\hline Kadar Abu Total $(\% \mathrm{~b} / \mathrm{b})$ & $0,99 \%$ \\
Kadar Air $(\%$ b/b) & $3,3119 \%$ \\
Susut Pengeringan $(\% \mathrm{~b} / \mathrm{b})$ & $4,79 \%$ \\
\hline
\end{tabular}

Panjang gelombang maksimum yang diperoleh pada penelitian ini yaitu $257.3 \mathrm{~nm}$ dan $358.2 \mathrm{~nm}$, panjang gelombang yang diambil untuk pembuatan kurva adalah 358.2 nm. Pengambilan panjang gelombang ini dimaksudkan agar tidak terganggu oleh absorbansi polimer yang terdapat pada range 240-260 nm. Hasil dari persamaan garis kurva yang diperoleh dengan persamaan garis $\mathrm{y}=0.0307 \mathrm{x}-0.0154$ dengan nilai $\mathrm{R}=$ 0.9998, yang menunjukkan garis regresi linear. Hasil total flavonoid yang diperoleh dari fraksi etil asetat daun sukun sebesar $32.7 \%$.

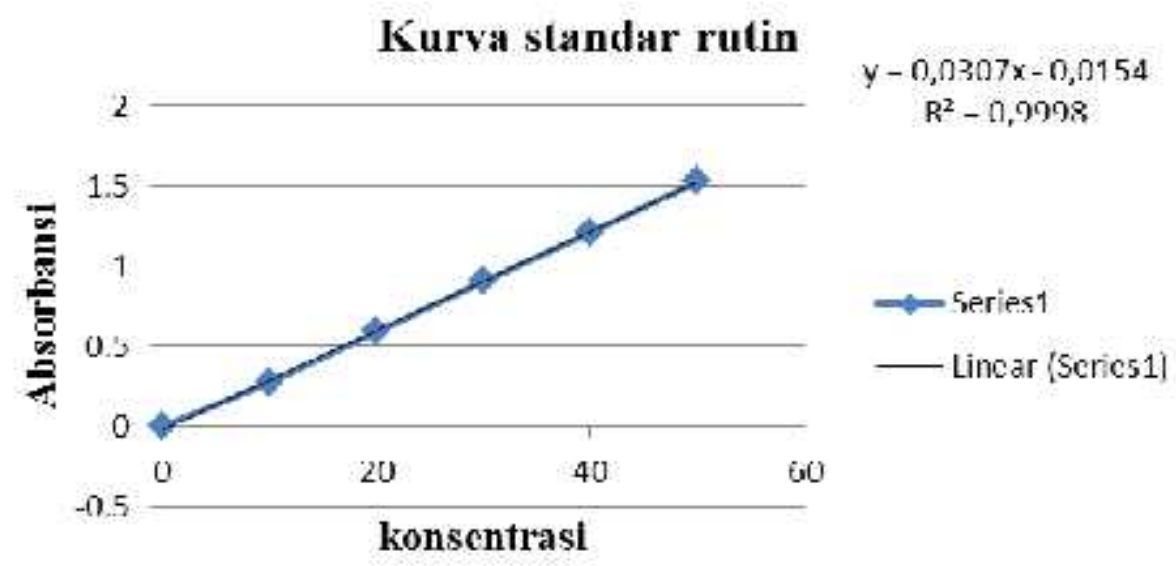

Gambar 2. Kurva Kalibrasi rutin

Pengujian parameter non-spesifik berupa kadar air, kadar abu total dan susut pengeringan. Kadar air yang diperoleh sebesar $3.31 \%$ telah memenuhi syarat sebagai bahan baku obat yang berasal dari alam karena memiliki nilai $<10 \%$ yang diharapkan mampu menekan laju pertumbuhan mikroba dalam fraksi etil asetat daun sukun (Kepmenkes,1994).

Kadar abu total menentukan karakteristik sisa kadar abu non-organik garam organik dan garam non-organik. Besarnya nilai kadar abu total sebesar $0.99 \%$ dalam serbuk fraksi etil asetat daun sukun menyatakan bahwa serbuk fraksi etil asetat memiliki kandungan mineral yang rendah. Susut pengeringan bertujuan untuk mengetahui rentang batas maksimal banyaknya senyawa yang hilang pada pada proses pengeringan dengan batas maksimal $<10 \%$ (Anonim, 2007). Hasil menunjukkan nilai susut pengeringan masih sesuai dengan 


\section{Karakteristik Campuran}

Peningkatan kelarutan suatu obat dapat dilakukan dengan penambahan polimer.Penambahan polimer dengan $\beta$ siklodekstrin biasanya terjadi dengan adanya pembentukkan kompleks inklusi. Karakterisasi campuran fisik dilakukan untuk mengetahui terjadinya pembentukkan kompleks inklusi dengan menggunakan Scanning Electron Microscopy dan titrasi Karl Fisher (Hadaruga, 2012).

\section{Scanning Electron Microscopy (SEM)}

Uji scanning electron microscopy (SEM) dilakukan untuk mengetahui perbedaan morfologi antara FEAS dan campuran FEAS dengan $\beta$ CD+HPMC.Perbedaan morfologi bertujuan untuk mengetahui adanya interaksi antara FEAS dengan penambahan polimer kombinasi yang diperkirakan terjadinya kompleks inklusi.

Hasil karakterisasi menggunakan Scanning Electron Microscopy(SEM) menunjukkan bentuk yang tidak terlalu berbeda signifikan satu dengan yang lainnya, namun pada formula 3 berbentuk seperti pada polimer kombinasi yang menyelimuti fraksi etil asetat daun sukun, namun hal ini tidak dapat memberikan informasi yang lebih jauh berkaitan dengan interaksi yang terjadi pada campuran fraksi etil asetat daun sukun - $\beta$ siklodekstrin+HPMC.

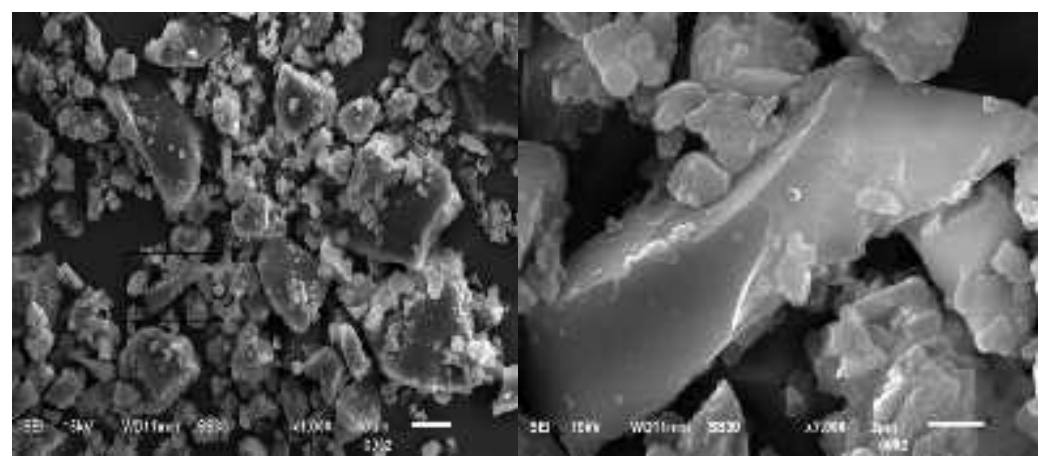

Gambar 8. Fraksi Etil Asetat Daun Sukun

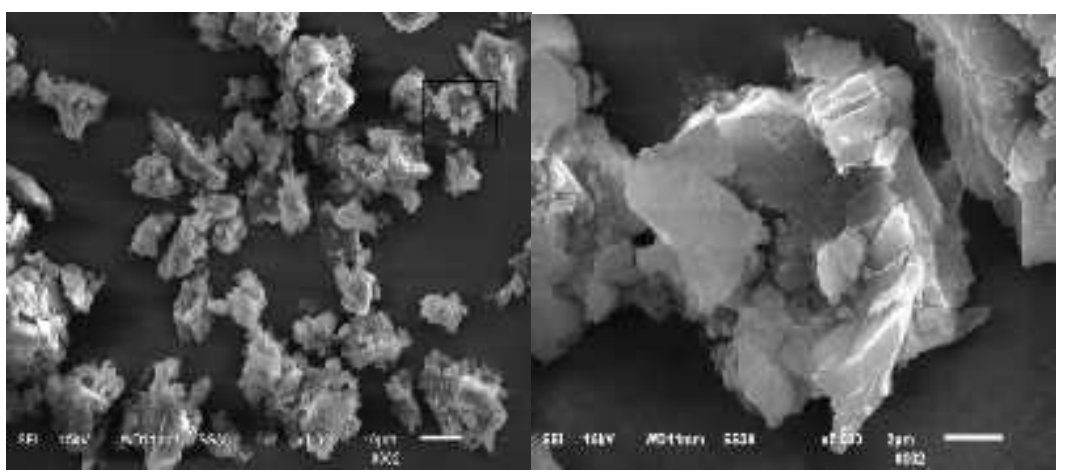

Gambar 9. Polimer kombinasi ß-siklodekstrin+ hidroksi propil metilselulosa

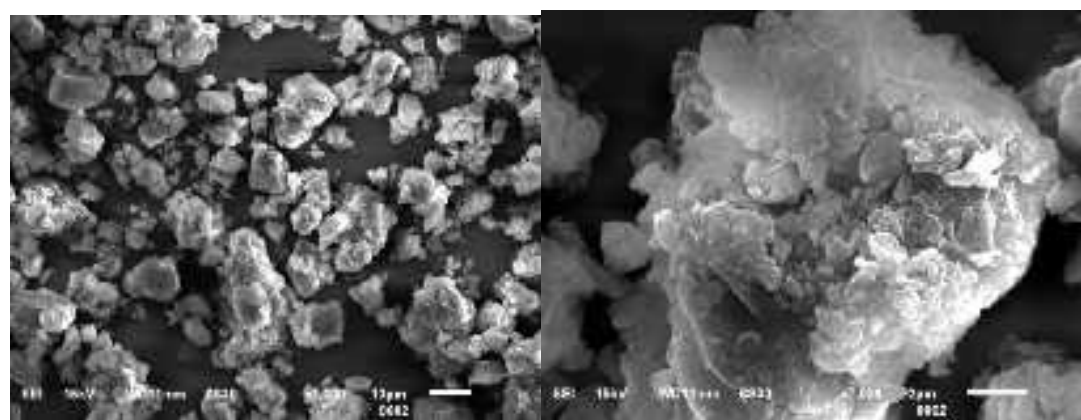

Gambar 10. Kompleks FEAS/ß-Siklodekstrin + Hidroksi propil metilselulosa 
Uji Karl Fischer Titration

Tabel 2. Hasil uji Karl Fisher titration

\begin{tabular}{|c|c|c|}
\hline Sampel & $\begin{array}{c}\text { Kadar air } \\
(\%)\end{array}$ & $\begin{array}{c}\text { \% Penurunan } \\
\text { Kadar Air pada } \\
\text { Formula } \\
\text { Terhadap } \\
\text { Kontrol }\end{array}$ \\
\hline Kontrol & 12.0537 & - \\
\hline Formula 1 & 7.0184 & 5.0353 \\
\hline Formula 2 & 7.7316 & - \\
\hline Formula 3 & 9.4152 & - \\
\hline
\end{tabular}

Keterangan :

Kontrol :pencampuran fisik FEAS: $\beta$-CD (1:2) dengan penambahan HPMC $0,12 \%$ terhadap bobot total FEAS dan $\beta$-CD sebelum perlakuan Kneading.

Uji karl fischer titration dilakukan untuk mengevaluasi kualitas proses kompleksasi, jika interaksi molekul tamusiklodekstrin sesuai maka rongga dalam siklodekstrin yang bersifat hidrofobik membentuk ikatan hidrogen dari molekul air tamu sehingga kadar airnya menurun dan diperkirakan terbentuk kompleks inklusi (Agrawal and Gupta, 2012).

Hasil karakterisasi yang telah dilakukan menunjukkan adanya penurunan nilai kadar air sebesar 5.0353 pada Formula 1dibandingkan terhadap kontrol. Penurunan nilai kadar air pada campuran siklodekstrin dengan molekul tamu menunjukkan bahwa kompleks inklusi diperoleh karena sebagian molekul air yang terdapat pada rongga bagian dalam $\beta$-CD digantikan oleh molekul tamu seperti flavonoid yang terdapat pada ekstrak yang diperkirakan membentuk ikatan hidrogen. Seperti pada penelitian yang dilakukan oleh Hadaruga (2012) pada tanaman Ficaria verna Huds- $\beta-\mathrm{CD}$ menggunakan metode pencampuran kneading menunjukkan penurunan kadar air dibandingkan dengan $\beta$-CD tunggal, hal ini dipengaruhi adanya interaksi molekul tamusiklodekstrin yang sesuai maka molekul air dari rongga bagian dalam siklodekstrin berikatan dengan molekul tamu sehingga terbentuknya kompleks inklusi (Hadaruga, 2012).

Pembuatan kontrol formula hanya dilakukan pada formula 1 sedangkan untuk kontrol formula 2 dan kontrol formula 3 tidak diuji karena keterbatasan biaya penelitian dan sampel. Hal ini menyebabkan kontrol formula 2 dan kontrol formula 3 dianggap sama dengan kontrol formula 1 karena penambahan polimer $\beta-C D$ pada setiap formulasi dianggap tidak akan memberikan perbedaan kadar air yang signifikan dibandingkan dengan kontrol formula 1 . Sehingga pada formula 2 dan formula 3 diperkirakan menunjukkan penurunan kadar air seperti pada formula 1 .

Hasil kadar air dapat dijadikan data pendukung pada pembentukkan kompleks inklusi dilihat dari penurunan nilai kadar airnya. Namun hasil dari penelitian ini tidak dapat dijadikan kesimpulan yang pasti mengenai terjadinya pembentukkan kompleks.Selain itu data pengamatan pada uji scanning electron microscopy juga tidak dapat mendukung data pembentukkan kompleks karena tidak terlihatnya perbedaan morfologi antara FEAS dengan campuran FEAS - $\beta$-CD+HPMC.

Data penunjang lain yang dibutuhkan untuk membuktikan terbentuknya kompleks inklusi tidak disertai dalam penelitian ini seperti QM (quantum mechanic) yang dapat memberikan informasi struktur 3 dimensi dari kompleks dan NMR yang dapat digunakan untuk menentukan arah penetrasi molekul tamu ke rongga bagian dalam siklodekstrin (Yan et al., 2006; Ramnik Singh et al., 2010).

\section{Uji Kelarutan}

Pada uji kelarutan fraksi etil asetat daun sukun menunjukkan hasilterjadinya peningkatan kelarutan fraksi etil asetat daun sukun dalam air pada masing-masing formula sebesar $7.04 \%, \quad 19.47 \%$ dan $59.92 \%$ dibandingkan kelarutan fraksi etil asetat daun sukun dalam air (tabel 3). 
Tabel 3. Hasil uji kelarutan

\begin{tabular}{|c|c|c|}
\hline Sampel & $\begin{array}{c}\text { Kadar } \\
\text { Total } \\
\text { Flavonoid } \\
(\%)\end{array}$ & $\begin{array}{c}\text { \% Peningkatan } \\
\text { Kadar Total } \\
\text { Flavonoid Formula } \\
\text { terhadap FEAS }\end{array}$ \\
\hline FEAS & 13,35 & $7,04 \%$ \\
\hline F1 & 14,29 & $19,47 \%$ \\
\hline F2 & 16,46 & $59,92 \%$ \\
\hline F3 & 21,43 & \\
\hline
\end{tabular}

Peningkatan kelarutan dianalisa menggunakan uji T.uji $\mathrm{T}$ yang digunakan yaitu paired sample untuk membandingkan sampel dengan formula dan indipendent sample untuk membandingkan formula dengan formula.

Dari data statistik uji $\mathrm{T}$ menggunakan paired sample dan indipendent sample terlihat adanya perbedaan peningkatan kelarutan fraksi etil asetat daun sukun pada campuran formula secara nyata dengan tingkat kepercayaan 95\% ( $\mathrm{p}<0.05)$. Hasil pada paired sample menunjukkan bahwa penambahan polimer kombinasi $\beta$ siklodekstrin+HPMC dapat meningkatkan kelarutan fraksi etil asetat daun sukun. Sedangkan hasil padaindipendent sample menunjukkan bahwa semakin banyak penambahan polimer kombinasi $\beta$ siklodekstrin+HPMC maka akan semakin meningkatkan kelarutan fraksi etil asetat daun sukun dalam air.

Dari data yang diperoleh terlihat bahwa semakin banyak jumlah ßsiklodekstrin maka semakin tinggi kelarutan fraksi etil asetat daun sukun dalam air. Peningkatan kelarutan ini dapat disebabkan karena terperangkapnya fraksi etil asetat daun sukun dalam rongga ß-siklodekstrin membentuk kompleks yang hidrofilik (Hiremanth, 2006). Sedangkan efek penambahan polimer larut air hidroksi propil metilselulosa pada komplek fraksi etil asetat daun sukun- $\beta$-siklodekstrin mempengaruhi daun sukun pada kompleks fraksi etil asetat daun sukun - $\beta$-siklodekstrin (Saraf et al., 2011.

Mekanisme penambahan polimer larut air pada pembentukkan kompleks terjadi karena polimer bertindak sebagai jembatan (penghubung) antara $\beta$ siklodekstrin dengan molekul tamu. Polimer larut air berikatan dengan rantai samping molekul tamu (obat), meningkatkan volume dan menjadikkan molekul tamu lebih cocok untuk masuk kedalam rongga $\beta$-CD (Valero, Tejedor, Rodrıguez., 2007).

Pada penelitian yang telah dilakukan, karaterisasi uji karl fischer titration pada tiap formula menunjukkan penurunan nilai kadar air terhadap kontrol formula disebabkan karena adanya interaksi antara molekul air rongga bagian dalam siklodekstrin dengan FEAS sehingga membentuk ikatan hidrogen yang mengakibatkan penurunan nilai kadar air. Hal ini diikuti dengan uji kelarutan yang menunjukkan terjadinya peningkatan kelarutan pada formula 1 , formula 2 , dan formula 3 terhadap FEAS dalam air. Oleh karena itu, hasil uji kelarutan dan uji karl fischer titration diperkirakan karena terperangkapnya molekul tamu yaitu FEAS kedalam rongga $\beta$-CD yang membentuk kompleks inklusi yang mampu meningkatkan kelarutan fraksi etil asetat daun sukun.Akan tetapi perlu dilakukan karakterisasi lainnya sebagai data penunjang terbentuknya kompleks inklusi menggunakan molekul tamu berupa ekstrak bahan alam yang terdiri dari senyawa multikomponen.

\section{SIMPULAN}

Penambahan polimer kombinasi $\beta$ siklodekstrin+Hidroksi propil metilselulosa dapat meningkatkan kelarutan fraksi etil asetat daun sukun pada masing-masing formula sebesar $7.04 \%, 19.47 \%$, dan $59.92 \%$.

\section{DAFTAR PUSTAKA}

Agrawal, R., Gupta, V., 2012, Cyclodextrins -A Review on PharmaceuticalApplication for Drug Delivery, IJPFR., 2(1): 95-112. 
Anonim, 2007, United States Pharmacopoeia 30th Edition. USA: The OfficialCompendia of

Ansel, Howard C.,1989,Pengantar Bentuk Sesiaan Farmasi, Jakarta, Universitas Indonesia

Aleem, O.M, Patil, A.L.,Pore, Y.V., Kuchekar, B.S., 2008, Cyclodextrin in Pharmaceuticals., An overview.

Azis, S., Rahayu, V., Teruna, H.Y., 2011, Standardisasi Bahan Obat Alam, Jakarta, Graha Ilmu.

Bekers, U., 1991, Siklodekstrins, In: The Pharmaceutical Field, Drug Dev. Ind. Pharm.,17(11)1503-49.

Challa, R., Ahuja, A., Ali, J., and Khar, R.K., 2005, Cyclodextrin in Drug Delivery: An Updated Review, AAPS PharmSci Tech.,6 (2):E329-E350.

Chandrakant, D. S., Danki, L. S., Sayeed, A., Kinagi, M. B., 2011, Preparation and Evaluation of Inclusion Complexes of Water Insoluble Drug, International Journal of Research in Pharmaceutical and Biomedical Sciences., ISSN: 2229-3701.

Chawla, G and Bansal, AK., 2008, Improved dissolution of a poorly water soluble drug in solid dispersions with polymeric and non-polymeric hydrophilic additives, Acta. Pharm., 58: 257-274.

Cirri M., Mura P., Rabasco AM and Ginés JM., 2004, Characterization of ibuproxam binary and ternary dispersions with hydrophilic carriers,AAPSPharmSciTech. 30(1): 65-74.

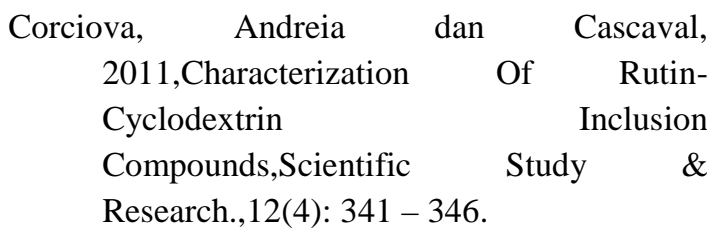

Cvetkovic, D., Markovic, D., Radovanovic, B., 2011,Effects of continuous UV-irradiation on the antioxidant activities of quercetin and rutin in solution in the presence of lecithin as the protective target, J. Serb. Chem. Soc., 76(7): 973-985.

Dalimartha, S., 2003, Atlas Tumbuhan Obat Indonesia, Jilid 3. Jakarta, Puspa Swara.

Departemen Kesehatan Republik Indonesia, 2000,Parameter Standar Umum Ekstrak Tumbuhan Obat, Jakarta.

Elbary,A., Kassem,M A.,Abou,S., and Khalil,R.,2008, Formulation and hypoglycemic activity of pioglitazonecyclodextrin inclusion complexes Drug
Standards.

Ferdianan A, Yuwono T, Wahyuningsih I., 2006,Peningkatan Kelarutan Piroksikan Melalui Pembentukan Kompleks dengan $\beta$ siklodekstrin, Media Farmasi., 5(2): 7-14.

Hiremath, S.N., Raghavendra, R.K., Sunil, F., Danki, L.S., Rampure, M. V., Swamy, P.V., Bhosale, U.V., 2008, Dissolution Enhancement of Glicazide by Preparation of Inclusion Complex with Bcyclodextrins, Asian Journal of Pharmaceutics., 73-76.

Hădărugă, Nicoleta G., 2012, Ficaria verna Huds. extracts and theirb-cyclodextrin supramolecular systems, Hădărugă Chemistry Central Journal.

Hussain, Md. Talib., Verma,A.,Vijayakumar, M., Sharma, Alok, C., Mathela, andRao,Ch. V., 2009, Rutin, a natural flavonoid, protects against gastric mucosal damage in experimental animals,Asian Journal of Traditional Medicines.

Lieberman, H.A., Lachman, L., \& Schwatz,J.B. (Eds.), 1989, Pharmaceutical Dosage Forms: Tablets Volume 1 Second edition, Revised and Expanded. New York: Marcel Dekker, 5, 17.

Mabry, A.J., Markham K.R., Thomas, M.B., 1970, The systemic Identification ofFlavonoids, Berlin.

Martin, A., Swarbrick, J., Cammarata, A., 1990,Farmasi Fisik Edisi Ketiga,Jakarta, UI-Press.

Patil, J.S., Kadam, D.C., Marapur, S.V., and Kamalpur, M. 2010. Inclusion Com[plex System : A Novel Techniques to Improve Solubility and Bioavailibility of Poorly Soluble Drugs : A Review. International Journal of Pharmaceutical Sciences Reviews and Research, 29-32.

Saraf, SA., Tripathi, GK., Pandey, M., Yadav, P., dan Saraf, SK.2011. Development of meloxicam formulations utilizing ternary complexation for solubility enhancement.Pak. J. Pharm. Sci., Vol.24, No.4, October 2011, pp.533-538.

Shargel, L., Andrew B.C Yu. 1988. Biofarmasetika dan farmakokinetika Terapan Edisi 2. Terj.dari Applied Biopharmaceutics and Pharmacokinetics, oleh Fasich, Siti Sjamsiah. Universitas Airlangga Press, Semarang: 96 - 100: 454 $-473$. 
Inclusion Complexes - A Review. Journal of Pharmaceutical Science and Technology Vol. 2 (3), 171-183.

Srikanth, M.V., Babu, M,G., Rao, N, S., Sunil, A., Balaji, S., Ramanamurthy, K. (2010). Dissolution Rate Enhancement Of Poorly Soluble Bicalutamide Using $\beta$ Cyclodextrin Inclusion Complex. International Journal of Pharmacy and Pharmaceutical Sciences Vol 2, Issue 1.

Szetjli, J. 1988. Cyclodextrin Technology. Dordrecht: Kluwer Academic Publishers, 104-106.

Umar, A., Jenie, L, Kardono., Mozef., T., Jiaan, C., Xiaoxiang, Z., Yuanjiang, P. 2007. Ekstrak Total Flavonoid dan Fitosterol Daun Sukun (Artocarpus altilis) sebagai Obat Kardiovaskuler dan Teknik Produksinya.Paten Indonesia terdaftar No. P00200700707.
Yan, C. Li, X. Xiu, L. Hao, B. (2006). A quantum-mechanical study on the complexation of b-cyclodextrin with quercetin. Journal of Molecular Structure: THEOCHEM 764, 95-100.

Valero, M, Tejedor, J, Rodriguez, L.J. (2007). Encapsulation of nabumetone by means of -drug : (b-cyclodextrin) :polyvinylpyrrolidone ternary complex formation. Journal of Luminescence 126 (2007) 297-302.

Vikesh, S., Rajashree, M., Ashok, A., Fakkirappa, M. (2009).Influence of $\beta$-Cyclodextrin Complexation on Ketoprofen Release from Matrix Formulation. International Journal of Pharmaceutical Sciences and Drug Research; 1(3): 195-202. 